(2020), 3 (1): 57-61

\title{
LISTENING DIFFICULTIES FACED BY THE FIRST SEMESTER STUDENTS AT BASIC LISTENING CLASS
}

\author{
Yahmun $^{1)}$, Endang Sumarti ${ }^{2)}$, Debby Setyowati ${ }^{3)}$, \\ ${ }^{12) 23)}$ IKIP Budi Utomo Malang \\ yahmun@budiutomomalang.ac.id
}

\begin{abstract}
This study aimed at describing difficulties faced by students in learning Listening. This study involved seventeen female students and eight male students taking Basic Listening course in one of private university in Malang, East Java. To gain the data, the researcher interviewed the subjects one by one. The findings, then, classified into several classes by referring to previous studies discussing listening difficulties in English as Foreign Language (EFL) classes. The findings showed that there were four difficulties faced by the students. They were the speed and length of the spoken text, vocabulary, pronunciation, and accents. Based on the findings, then, the researchers made several suggestions for further researchers and other language teachers to consider this study in their practice.
\end{abstract}

Keyword: EFL, listening skills, difficulties

CPendidikan Bahasa Inggris FPISH IKIP BU Malang

\section{Introduction}

In the process of teaching and learning English as a Foreign Language (EFL), listening becomes one of important skill that the students need to master. This is so because listening, as a receptive skill, provide students input of the language. By listening, students are expected to get language input before they produce the language in forms of spoken and written.

Djiwandono (2008) says Listening is mainly related to the ability to understand the meaning of a form of language use that is expressed orally. In addition, listening is the ability to identify and understand what others are saying. This involves understanding a speaker's accent or pronunciation, his grammar and his vocabulary, and grasping his meaning (Howatt and Dakin, 1974). While according to Rost (1991) "Listening is an active process requiring participation on the part of the listener". For example, when someone listens to a speaker, he/she processes the information mentally in order to construct an answer. During the listening process the listener is actively engaged. In learning a foreign language, it is important to listen to what is transmitted with a great deal of attention because this helps the listener to reproduce exactly, or almost exactly, what he/she hears. Therefore, listening is not an isolated skill; we listen in order to understand what has been heard.

Listening is a complex problemsolving skill and it is more than just perception of the sounds. Listening includes comprehension of meaning words, phrases, clauses, sentences, and connected discourse oxford (1993: 206). Furthermore, Rivers (2006: 8) says that listening is a creative skill. It means we comprehend the sound falling on our ears, and take the raw material of words, arrangements of words, and the rise and fall the voice, and from this material we creative a significance. Russel in Hasyuni (2006:8) also say that listening skill is listening with comprehension, attention and appreciation. Then, listening activity. needs integrating skill of language, such as pronunciation, 
vocabulary. mastery, writing, speaking, and reading.

Listening skill can be meant as ability to pay attention or to hear something. But, listening is not same as hearing. Hearing is essentially an automatic, passive activity. It is possible to hear sounds without consciously engaging in the process. While, in listening the brain doesn't automatically translate the words into the message they are conveying. That is essentially what listening is determining the meaning and the message of the sounds or words. It is active process that involves much more than assigning labels to sounds or words. As mentioned in Mee (1990), listening is a complex process in which many things happen simultaneously inside the mind. Besides being complex, listening is far more difficult than many people can imagine.

\section{Moreover Nunan}

(2003:24)

"Listening is an active, purposeful process of making sense of what we hear." It means that, we should interpret the meaning from what we hear, therefore listening is an active skill. So, we can say that listening is the ability to identify and understand what others are saying. It is also a complex activity, and we can help students comprehend what they hear by activating their prior knowledge. Listening is the active process because listening is not just matter of hearing, listening include many process. Listening is determining the meaning and the message of the sound.

Listening is a great process of getting to know and interpret oral symbols (Russell \& Russell in Tarigan, 2008: 30). Listening also means listening with understanding and attention and appreciation (Russell \& Russel; Anderson in Tarigan, 2008: 30). In line with this understanding, listening also means something the process of listening to verbal symbols attentively, understanding, appreciation, and interpretation to obtain information, capture content or message, and understand the meaning of communication that has been conveyed by the speaker through spoken or spoken language (Tarigan, 2008: 31). Meanwhile Rost (1991) says that "Listening is an active process requiring participation on the part of the listener". In addition Djiwandono ( 2008), says Listening is mainly related to the ability to understand the meaning of a form of language use that is expressed orally.

From the definition above, we can say that listening is the ability to identify and understand what others are saying. It is also a complex activity, and we can help students comprehend what they hear by activating their prior knowledge.

Regarding the complexity process which take place during listening process, it is quite understandable that listening often viewed as difficult skill to be learned. This fact has been revealed by some studies; one of which was conducted by Darti and Asmawati (2017). The investigated the second semester of English Department students who took Listening class at one of state universities in Indonesia. Darti and Asmawati (2017) found out that there were three factor which make Listening difficult for the students. Those factors included listening materials which covered accents, pronunciation, length of speech, bad quality of the recorder. The next two factors were listener factors and physical setting. Further they explained that listener factors dealt with students' insufficient vocabulary and lack of concentration during the class; meanwhile, physical factors referred to classroom setting. Other study discussing problem in Listening class was carried out by Gilakjani and Sobouri (2016). These two scholars discussed listening problems as it was stated by Binglol et.el (2014). Gilakjani and Sobouri (2016:127) summarized that there are five common problems faced by learners in the 
class. Those problems are the quality of the materials, different cultures between the learners and the learned language, accents, vocabulary, and the length and the speed of the listening.

Similar to those previous studies, this study was also intended to find out students' obstacles in listening class. Although this paper discusses similar topic, this paper is still significantly different from the previous ones. This article is different from the one written by Darti and Asmawati (2017) because the subjects in this study were students of English department at one of private university in Est Java. The subjects were attending Basic Listening class at 2019/2020 academic year. By having, different subjects, the researcher believed that he could find data to support, to add, or to reject previous insights on listening difficulties. Compared to Gilakjani and Sobouri (2016:127), this study is also different. Gilakjani and Sobouri (2016:127) limited their study on analyzing theoretical framework of listening problems faced by English as Foreign Language (EFL) learners without providing field data; differently, this study discussed about learning listening difficulties faced by students in the field.

\section{Research Method}

This study used qualitative method to gain the intended findings. This was so because this study intended to describe the student difficulties in learning listening skills. To get the data, the researcher interviewed 25 students who took Basic Listening class during 2019/2020 academic year. The interview was done in the middle of the semester. The interview guide was used to help the researcher to stay on the tract or to focus on asking listening difficulties. After the students' answers were collected, they were classified and interpreted. Next, the findings were compared and contrasted to the existing insights of listening difficulties faced by ELF learners.

\section{Result and Discussion}

The results of the interview showed that there were four main difficulties faced by the students. Those difficulties included the record speed and length, vocabulary, pronunciation and accents. To some extends, this findings have similarities with studies conducted by Darti and Asmawati (2017), and Binglol et.el (2014 in Gilakjani and Sobouri, 2016:127). Meanwhile, other difficulties highlighted by the previous scholars, like physical setting and quality of the record, were not found in this study.

The most common difficulties faced by the students were the speed and the length of the record. One hundred percent of the students, or 25 students, agreed that the speakers in the record spoke too fast. Therefore, it was hard to take a note. As a result, the cannot check the meaning of the word in their electronic dictionary. Besides, the spoken text was also too long so that they could not remember what the speakers had said. This lead the students into complete confusion when they were to answer the questions. This support listening difficulties insight stated by Binglol et.el (2014 in Gilakjani and Sobouri, 2016:127).

Next listening difficulties found in this study was students limited vocabulary. this was also elicited by all the students attending Basic Listening class at A1 class. They said that most of the vocabulary was still new for them; so, it was hard for them to understand the content of the record. This particular finding is also still in line with Binglol et.el (2014 in Gilakjani and Sobouri, 2016:127). In addition, this data also supported Darti and Asmawati (2017) who also concluded that vocabulary became one of obstacles in learning listening skill. 
In addition to the two listening problems, $92 \%$ of the students admitted that pronunciation was also parts of the listening problems. One of the subject, $\mathrm{NH}$, said that she was trying to check in the dictionary but she could not find it because she did not know the spelling of the word that was uttered by the model in the record. This, again, confirmed listening difficulties discussed in the two previous studies.

The last problem found in this study was accent. Twenty out of twenty-five students said that they were frequently confused with different accents used by the models. Some subjects like AK, LA, and SM explained that they wondered when they found out the word "day" uttered differently by different models; One said [dei], the other one in the other record said [dai]. From this specific finding, we can see the red thread between this study and the previous one: accent, sometimes, can be confusing for the EFL learners who did not use to different accent used by native speakers of English.

\section{Conclusion}

From the findings above we can conclude that students taking English at university levels still found difficulties in digesting meaning of spoken text in Basic Listening class. The findings provide the researcher and other English teachers to be more aware of this difficulties since student listening skill is one of the very basic and important skill in learning language. If students fail to develop their listening skill, the researcher is afraid that they will fail in developing the other skills. This is so because in learning other language skills like Speaking, Reading, and Writing, the students still need to listen to their teachers' explanation which still use spoken English as the medium of instruction.

Based on the conclusion, therefore, the researcher would like to make some suggestions for some parties as further researchers and other language teachers. Further researchers are encouraged to conduct research in similar topic but use different research method like Classroom Action Research or experimental research to find out some strategies to minimize teaching and learning listening difficulties. Next, other teachers are suggested accommodate the finding of this study so that they can adapt or adopt appropriate teaching listening materials. Besides they are also expected to teach their students some listening strategies to help the students to minimize their problem in listening class.

\section{References}

Darti and Asmawati, A. (2017). Analyzing Students' Difficulties Toward Listening Comprehension. ETERNAL: an online journal. No 3 (2). Retrieved from http://journal.uinalauddin.ac.id/index.php/Eternal/arti cle/view/4592/4458 on January $15^{\text {th }}$, 2020.

Djiwandono, S, (2008). Tes Bahasa, Pegangan Bagi Pengajar Bahasa, Edisi 2 ... Terbitan: Jakarta : Indeks, 2008

Gilakjani, A.P. and Sobouri, N.B. (2016). Learners' Listening Comprehension Difficulties in English Language Learning: A Literature Review. English Language Teaching Journal. No 6. (9). Retrieved from https://files.eric.ed.gov/fulltext/EJ11 01226.pdf

Hasyuni (2006). The Students' Preferred Activities for English Listening Classes (A Survey Conducted to the Second and Fourth Semester Students of English Department of FKIP Universitas Bengkulu Academic Year 2005/2006). Unpublished Thesis of Teacher 
Training and Education Faculty of Universitas Bengkulu

Howatt, A. and J. D. (1974). Language laboratory materials, ed. J. P. B. Allen, S.P. B. Allen, and S. P. Corder.

Mee, M., Y. (1990). Teaching Listening: An Overview. The English Teacher Vol XIX.

Nunan, D. (2003). Practical English Language Teaching. New York: Mc Graw Hill. Fulcher

Oxford, R.L. (1993). Research update on teaching L2 listening.

Rost, M. (1991). Listening in action: Activities for developing listening in language teaching. New York: Prentice Hall.

Tarigan, H., G. (2008). Membaca sebagai Suatu Keterampilan Berbahasa. (Bandung: Angkasa). 